\title{
Deposit Performance Analysis: A Comparison of Conventional and Islamic Banks in Bangladesh
}

\author{
Tasneema Khan \\ Department of Banking and Insurance, Faculty of Business Studies, University of Dhaka, Dhaka, Bangladesh \\ Email address: \\ tasneemakhan@du.ac.bd
}

To cite this article:

Tasneema Khan. Deposit Performance Analysis: A Comparison of Conventional and Islamic Banks in Bangladesh. International Journal of Economics, Finance and Management Sciences. Vol. 6, No. 4, 2018, pp. 165-173. doi: 10.11648/j.ijefm.20180604.14

Received: June 9, 2018; Accepted: June 26, 2018; Published: July 23, 2018

\begin{abstract}
Deposit is considered to be the most important source of a banks' fund, which plays a significant role in running a banking industry. Existence and expansion of banks are mainly influenced by their ability to attract deposits from different segments of the society. Although every bank expects that flow of deposits will be sufficient and smooth, changes in economic and commercial activities make deposit management more challenging to the bank managers. As deposit is considered the lifeblood of a bank, analyzing the deposit performance has become a key factor to evaluate a banks overall performance [10]. In banking industry of Bangladesh, Islamic banks are operating successfully besides other conventional banks. Although they are few in number in the industry, Islamic banks are performing well ahead in comparison with conventional banks in some respect [13]. Therefore, to evaluate the performance of both types of banking system, deposit performance has been taken as the basis of comparison. Though the deposit schemes of both types of banks are almost similar there are differences in techniques applied in the process of deposit mobilization by these two banking systems [1]. Therefore this study aims at measuring deposit performance of both types of banks in Bangladesh, comparing their position and identifying in which aspect Islamic banks are ahead of conventional banks and in which area conventional banks are performing better. For this purpose, all the Private Commercial Conventional Banks (PCCBs) and Islamic Banks (IBs) of Bangladesh have been studied for last 10 consecutive years ranging from 2007 to 2016. Using some variables like total deposit, segment wise deposit, categories of deposit, growth rates and productivity aspect, this study shows that PCCBs are ahead if total amount is measured but in terms of growth and productivity IBs show better performance. This can be considered as a very time proven and rational study since no other study concerned on such issue earlier in Bangladesh. These results would help both types of banks know their position in terms of deposit performance and thus also reflect the performance of banking sector as a whole since these two types of bank together constitute almost seventy percent of banking industry in Bangladesh.
\end{abstract}

Keywords: Conventional Banks, Islamic Banks, Deposit

\section{Introduction}

Mobilization of deposits largely influences the extent of loan and investment activities of a particular bank. Commercial bank, either conventional or Islamic, requires monitoring and managing its deposit effectively and efficiently. Though, both conventional and Islamic banking have enormous contribution to the economy of Bangladesh they have some major differences [17]. Especially conventional banks follow interest based banking system while Islamic banks follow Islamic Shariah based mechanism where interest is strongly prohibited [8]. It is evident that Islamic banks in Bangladesh are performing better in some aspects than other conventional banks though they are quite few in number $[13,6]$. Therefore, a comparative study on deposit performance would surely be insightful to know their actual position since deposit is considered the key to measure overall performance of a bank. Islamic banks offer deposit products under concepts of guaranteed custody or Al-Wadiah and investment deposits under concepts of profit sharing or Al- Mudarabaha [8]. Where as all the activities including deposit mobilization of conventional banks are interest based. Deposit performance of banks varies according to their ability to mobilize different types of deposit, growth of deposits over years, and collection of deposit from public and private sector. 
The main objective of this study is to analyze and compare the deposit performance of Islamic banks with that of private commercial conventional banks in Bangladesh.

This study would contribute to the current literature and research in several ways. (i) This would be the very first of kind in comparing deposit performance between conventional and Islamic banks in Bangladesh. (ii) Several determinants have been used in this paper while comparing deposit of both types banks. (iii) The study covers the deposit scenario for both types of banks over last 10 years. (v) This paper would provide information to depositors, equity holders, investors and banks management about their deposit management condition.

Although the best effort has been given to make this study comprehensive, this may lack some of the required aspects. The major point of limitation while conducting this study is up to date information was not published as a result the analysis could not be performed over 2017.

\section{Literature Review}

Comparison of Islamic banks and conventional banks in terms of various performance indicators has been a matter of great interest to various researchers in recent times. It is apparent that failure of large banks throughout the world has called for concentration on the Islamic banking system and comparison of Islamic banking with conventional banking system [14]. Therefore, considerable numbers of studies have been conducted on performance of Islamic banking system all over the world. It is evident that the performance analysis is based on profitability analysis [13, 17], CAMELS analysis [1], deposit performance [10], financial performance analysis $[6,11,15]$ and such other indicators.

Hanif (2011) attempted to find out the differences and similarities in Islamic and conventional banking. He pointed out that there exist some differences in mechanism of funds mobilization from savers to entrepreneurs in Islamic banking. One of the major points identified is that under conventional system reward is fixed and predetermined while under Islamic system deposits are accepted through Musharaka and Mudaraba where reward is variable [7].

Sarker, Sultana, and Prodhan (2017) have conducted a study on Al-Arafah Islami Bank Limited of Bangladesh and analyzed their financial performance using some financial indicators and ratios. It has been found that profitability of the bank was not quite satisfactory over the five studied years (2010-2014). It showed negative trend during 2012-2014. Branch productivity and branch profitability showed an acceptable performance. But the solvency and liquidity position of the bank were not steady. The authors suggest the bank to follow shariah principles properly and increase their financial products to make a better performance [15]. Another study has also been found on financial performance analysis of Islami Bank Bangladesh Limited. Chakraborty, Salam, and Rabbany (2015) have evaluated the banks performance by profitability, solvency, liquidity and productivity ratio over 2006-2010. The bank showed fluctuating results except for productivity aspect, which was in increasing trend [5].

While analyzing Islamic banking system in Bangladesh and all over the world, Salahuddin, Islam and Islam (2014) have found that most of the Islamic banks in Bangladesh proved to be profitable except for ICB Islami Bank Limited [17]. Both qualitative and quantitative approaches have been used in this study to analyze the performance of Islamic banks in Bangladesh.

Al Mahmud and Islam (2011) in their study showed the comparison of the performance of conventional and Islamic banking system in Bangladesh. Adopting some widely used measures such as general business measures, profitability ratios, management soundness and social profitability measures, the study shows that in spite of a few exceptions, Islamic banks' overall performance was better than the conventional banks [2]. In this study, Islami Bank Bangladesh Limited is selected to represent the mechanism of Islamic banking in Bangladesh. In addition, it identifies some of the shortcomings of Islamic banks in Bangladesh and also suggests some solutions.

Sarker (2013) has conducted study on "Islamic Banking in Bangladesh-Growth, Structure, and Performance” where he has focused on the history of Islamic banking system and its performance along with the overall performance of banking system in Bangladesh. Contribution of Shariah council on the performance of Islamic bank has also been discussed in this report. Along with the performance analysis, some suggestions have been given regarding improvement of Islamic banking system in Bangladesh.

One of the most important performance indicators used, as basis for comparison is deposit on which a literature has been found from Bangladesh perspective. In this regard Kabir, Qayum and Islam (2013) examined the efficiency of deposit management of Islamic Bank Bangladesh Limited (IBBL) and Pubali Bank Limited (PBL). The analysis period was from 2006 to 2010 . This study was conducted on the basis of current deposit, time deposit, saving deposit, total deposit and some deposit ratios. Significant difference of deposit management found for IBBL and the PBL but there were no differences in deposit management. The major finding of the study is that deposit management of IBBL is more efficient than that of the PBL [10]. Deposit comparison of Islamic banks and conventional banks in Bangladesh has also been found in the study of Mahbub and Dilshed (2016). In this study total deposit, growth of deposit, deposit per employee, deposit per branch and average deposit over 2008-2013 have been analyzed.

It is evident that there have been studies on overall status, prospect and performance of Islamic banking in Bangladesh. Where much focus is given on individual Islamic banks or some selected banks and their performance. From comparison aspect between conventional and Islamic banks of Bangladesh, there are studies regarding financial performance, CAMELS and profitability measures. However, no study has been conducted taking all the private conventional banks and all the Islamic banks into account in 
the banking industry of Bangladesh in comparing the deposit performance. Therefore this study would contribute to the previous study by focusing on different aspects of deposit performance of all the private conventional banks and all the Islamic banks which will take a comprehensive look in to the significant differences of deposit between these two banking system of Bangladesh over last ten consecutive years.

\section{Methodology}

\subsection{Sample and Data}

At present, 57 scheduled banks are operating in banking industry of Bangladesh among which there are 6 state-owned commercial banks, 2 specialized banks, 9 foreign commercial banks and 40 private commercial banks [3]. Again, private commercial banks are categorized as private conventional and private Islamic banks [11]. This paper is concerned about the differences in deposit performance of conventional banks and Islamic banks in Bangladesh. So existing local private commercial banks including conventional and Islamic banks have been selected to make the comparison justified. This analysis has been conducted over 10 years' time period ranging from 2007 to 2016 . While conducting this study, it has been evident that the number of private commercial banks was not same in each of the studied year. During this 10 years period, 9 new banks entered into the industry in 2013 (8 conventional and 1 Islamic) and a new conventional bank started its operation in 2016 [3, 17]. Interestingly, a conventional bank, First Security Bank Limited, turned into Islamic bank in 2009 and named as First Security Islamic Bank Limited [3]. Therefore, this study has been conducted accordingly considering all the conventional and Islamic banks for each of the studied year. Table 1 shows the studied number of banks:

Table 1. Overview of the Studied Banks.

\begin{tabular}{llll}
\hline Year & No. of PCCBs & No. of IBs & Total PCBs \\
\hline 2007 & 24 & 6 & 30 \\
2008 & 24 & 6 & 30 \\
2009 & 23 & 7 & 30 \\
2010 & 23 & 7 & 30 \\
2011 & 23 & 7 & 30 \\
2012 & 23 & 7 & 30 \\
2013 & 31 & 8 & 39 \\
2014 & 31 & 8 & 39 \\
2015 & 31 & 8 & 39 \\
2016 & 32 & 8 & 40 \\
\hline
\end{tabular}

Source: Scheduled Banks Statistics by Bangladesh Bank.

\subsection{Types of Data}

Both quantitative and qualitative data have been collected for conducting this paper. At the beginning, data on history of banking industry in Bangladesh, types of banks, numbers of banks and their respective branches, establishment year and number of employees have been collected. Afterwards this paper focuses on the comparison of deposit performance of conventional banks and Islamic banks which requires data on types of deposit, deposit management process, principles of deposit mobilization, amount of total deposit, amount of deposit in terms of sector and types for each of the conventional and Islamic banks over last ten years.

\subsection{Sources of Data}

In order to meet the objectives of the study, data were collected from some secondary sources such as financial reports of the banks, publications of Bangladesh Bank and Ministry of Finance, and other relevant reports.

The following sources have been used for the purpose of gathering and collecting data as required.

Secondary Data Source:

a) Activities of Banks, Insurance and Financial Institutions -Ministry of Finance (People's Republic of Bangladesh)

b) Financial statements of scheduled banks

c) Websites of Bangladesh Bank and other scheduled banks

d) Scheduled Bank Statistics by Bangladesh Bank (20062016)

e) Financial Stability Report by Bangladesh Bank (20062016)

f) Different books and articles regarding Deposit Management of Conventional Banks \& Islamic Banks.

g) Bangladesh Bank Bulletin

\subsection{Methods of Data Analysis}

To analyze the collected data, the following techniques have been applied:

\subsubsection{Comparative and Graphical Analysis}

In order to make the comparison more visual, along with tabular analysis related graphs and charts have also been used. Graphical analysis covers variables like total deposit, sector wise deposit, types of deposit, growth aspects and productivity aspects.

\subsubsection{Growth Analysis}

Growth rates are the percentage change of a particular variable over a specific time. It has been applied over the variables related to comparison and calculated as follows:

$$
\text { Growth Rate }=\frac{\text { Current Year's Value }- \text { Base Year's Value }}{\text { Base Year's Value }}
$$

\subsubsection{Productivity Analysis}

Productivity has been measured in terms of total branch and total employee. Branch productivity indicates how efficient the branches are for each type of banks in mobilizing deposit. It is calculated by dividing the total deposit for each year by that year's total number of branches [15]. Similarly, employee productivity has been measured by dividing total deposit by respective total number of employees for each group of banks. It indicates the efficiency of employees of particular type of bank in mobilizing deposit. 


\subsubsection{Averaging Techniques}

Simple average technique for ten years has been applied over some variables such as employee productivity, branch productivity, market share of deposit, growth rate of total deposit, time deposit and demand deposit.

\section{Analysis and Discussion}

Differences in deposit performance between conventional and Islamic banks are shown here under several variables:

\subsection{Total Deposit by Types of Banks}

Total amount of deposit is different for the private commercial conventional banks and Islamic banks. Table 2 shows total deposit of both PCCBs and IBs over the last ten years. Total deposit of both PCCBs and IBs show a rising trend over the last ten years. But Islamic bank's total deposit were significantly lower than that of conventional banks, which is quite justified since the total number of banks and branches of PCCBs are substantially higher than that of IBs. Here Figure 1 represents the total amount of deposit by both types of banks.

Table 2. Total Deposit by Types of Banks.

\begin{tabular}{lll}
\hline Year & PCCBs & IBs \\
\hline 2007 & 836713.2 & 282912.5 \\
2008 & 1062663.1 & 352512.2 \\
2009 & 1330953.8 & 473612.8 \\
2010 & 1648995.1 & 594430.4 \\
2011 & 2005778.8 & 740287.5 \\
2012 & 2424188.1 & 939155.7 \\
2013 & 2737102.7 & 1078216.5 \\
2014 & 3155778.9 & 1335201.5 \\
2015 & 3576961.9 & 1539585.3 \\
2016 & 4067996.5 & 1759191.5 \\
\hline
\end{tabular}

Source: Activities of Bank, Insurance and Financial Institutions by Ministry of Finance.

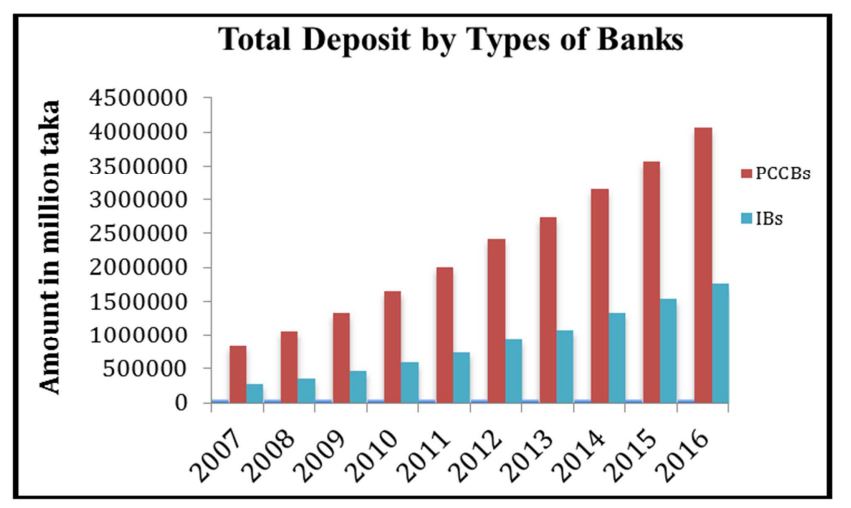

Figure 1. Total Deposit by Types of Banks.

Source: Activities of Bank, Insurance and Financial Institutions by Ministry of Finance.

\subsection{Growth of Total Deposit by Types of Banks}

Although total deposits of Islamic banks were significantly lower than that of conventional banks, deposit growth rates of Islamic banks show a different scenario. Islamic bank's deposit growth rates were higher for all the years except for 2008. Average growth rates of deposit show that performance of IBs was better than that of PCCBs as average growth rate for Islamic banks over last 10 years was $22.48 \%$ whereas the result was $19.32 \%$ for private conventional banks. Another trend reveals that total deposit of PCCBs increased at a decreasing rate as from 2008 to further the growth rate gradually decreased which slightly recovered in 2014 but then fluctuated again. On the other hand, IBs deposit growth shows a very fluctuating trend. Total deposit growth of IBs fell sharply in the year 2013. Afterwards it improved well but again the rate fell in 2015.

Table 3. Growth of Total Deposit.

\begin{tabular}{lll}
\hline Year & PCCBs & IBs \\
\hline 2007 & $19.26 \%$ & $20.69 \%$ \\
2008 & $27.00 \%$ & $24.60 \%$ \\
2009 & $25.25 \%$ & $34.35 \%$ \\
2010 & $23.90 \%$ & $25.51 \%$ \\
2011 & $21.64 \%$ & $24.54 \%$ \\
2012 & $20.86 \%$ & $26.86 \%$ \\
2013 & $12.91 \%$ & $14.81 \%$ \\
2014 & $15.30 \%$ & $23.83 \%$ \\
2015 & $13.35 \%$ & $15.31 \%$ \\
2016 & $13.73 \%$ & $14.26 \%$ \\
Average Growth Rate & $19.32 \%$ & $22.48 \%$ \\
\hline
\end{tabular}

Source: Activities of Bank, Insurance and Financial Institutions by Ministry of Finance.

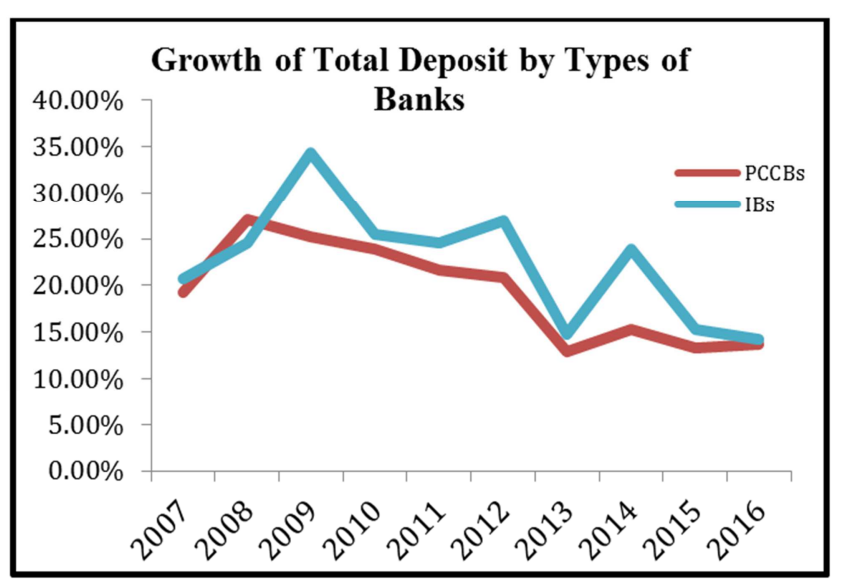

Figure 2. Growth of Total Deposit.

Source: Activities of Bank, Insurance and Financial Institutions by Ministry of Finance

\subsection{Market Share of Total Deposit by Types of Banks}

Table 4 shows the market share of total deposit occupied by certain types of banks for a particular year.

Table 4. Market Share of Total Deposit.

\begin{tabular}{lll}
\hline Year & PCCBs & IBs \\
\hline 2007 & $74.73 \%$ & $25.27 \%$ \\
\hline
\end{tabular}




\begin{tabular}{lll}
\hline Year & PCCBs & IBs \\
\hline 2008 & $75.09 \%$ & $24.91 \%$ \\
2009 & $73.75 \%$ & $26.25 \%$ \\
2010 & $73.50 \%$ & $26.50 \%$ \\
2011 & $73.04 \%$ & $26.96 \%$ \\
2012 & $72.08 \%$ & $27.92 \%$ \\
2013 & $71.74 \%$ & $28.26 \%$ \\
2014 & $70.27 \%$ & $29.73 \%$ \\
2015 & $69.91 \%$ & $30.09 \%$ \\
2016 & $69.81 \%$ & $30.19 \%$ \\
Average Market Share & $72.39 \%$ & $27.61 \%$ \\
\hline
\end{tabular}

Source: Activities of Bank, Insurance and Financial Institutions by Ministry of Finance

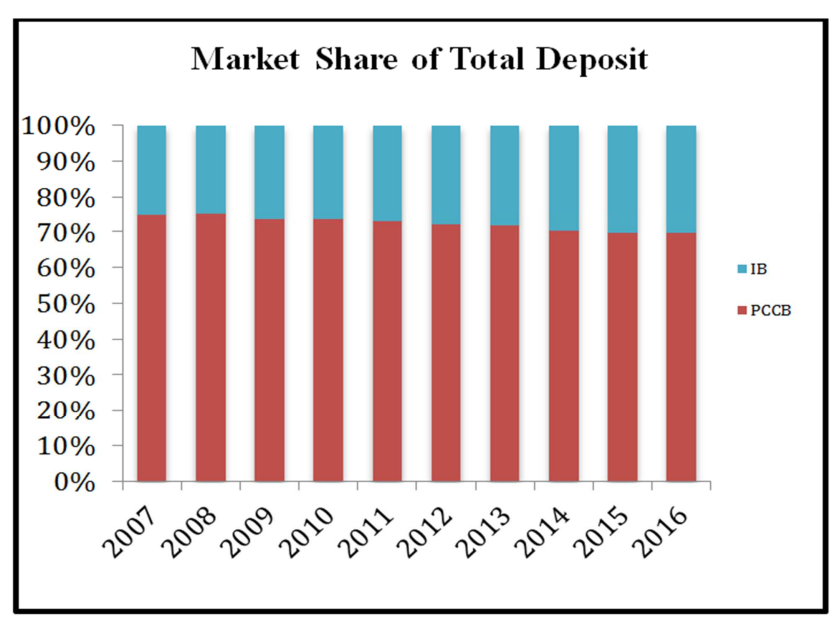

Figure 3. Market Share of Total Deposit.

Source: Activities of Bank, Insurance and Financial Institutions by Ministry of Finance.

Here the market share of total deposit of PCCBs is much higher than that of Islamic banks. IBs market share of total deposit decreased from 2007 to 2008 but it shows rising trend over the subsequent years. And the reverse happened for the PCCBs. From 2008 to 2016, PCCBs market share of total deposit gradually decreased, which suggests IBs were capturing the market well. The average market share is $72.39 \%$ for PCCBs and $27.61 \%$ for IBs over last 10 years.

\subsection{Public Sector and Private Sector Deposit by Types of Banks}

Bank deposits in Bangladesh can be broadly categorized as public sector and private sector deposit. Deposits of government sector (ministries, autonomous bodies and semi govt. organizations) and other public sector (other than govt.) are termed as public sector deposit. And deposits of various private sectors such as agriculture, manufacturing, trade and commerce, transport, construction, publishing, private educational institution, other financial intermediary, professional and self-employed person, non-profit organization, foreign offices and individuals are included under private sector deposit [12]. In terms of private and public sector deposit, both PCCBs and IBs scenario are as follows:
Table 5. Public Sector Deposit.

\begin{tabular}{cll}
\hline Year & PCCBs & IBs \\
\hline 2007 & 74192.1 & 15214.9 \\
2008 & 98559 & 29253 \\
2009 & 138705 & 49694.4 \\
2010 & 174013.2 & 49632.6 \\
2011 & 202104 & 40590.8 \\
2012 & 224814.9 & 41523 \\
2013 & 218688.9 & 64893.4 \\
2014 & 265724.3 & 77349.5 \\
2015 & 369440.6 & 103779.2 \\
2016 & 445712 & 119344.9 \\
\hline
\end{tabular}

Source: Scheduled Bank Statistics by Bangladesh Bank.

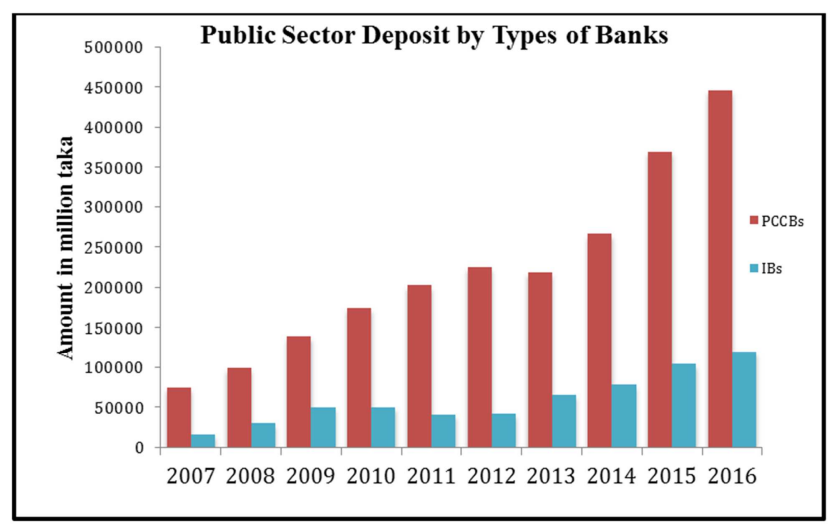

Source: Scheduled Bank Statistics by Bangladesh Bank.

Figure 4. Public Sector Deposit.

Figure 4 illustrates that public sector deposits were higher for PCCBs and it shows rising trend in public sector deposit. PCCBs public sector deposit rises sharply during 2015 and 2016. Where as IBs have a very fluctuating trend in public sector deposit.

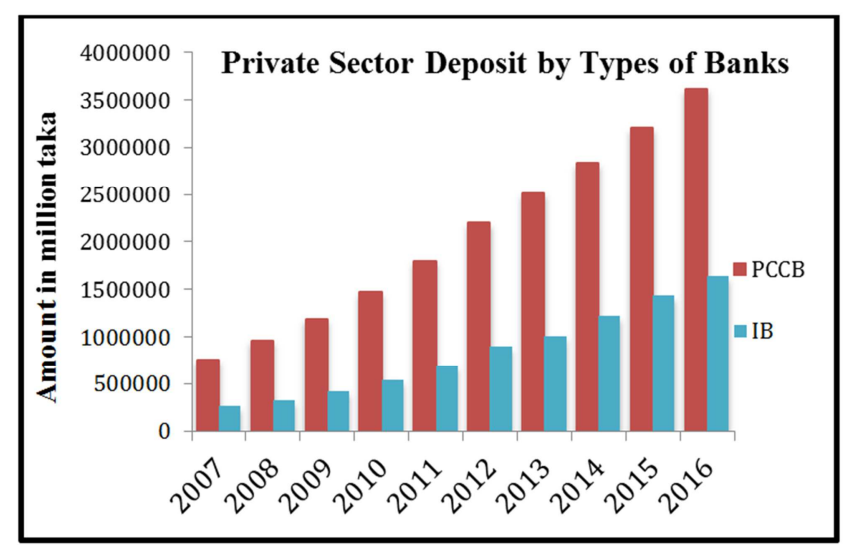

Source: Scheduled Bank Statistics by Bangladesh Bank.

Figure 5. Private sector Deposit.

Table 6. Private Sector Deposit.

\begin{tabular}{cll}
\hline Year & PCCBs & IBs \\
\hline 2007 & 762521.1 & 267697.6 \\
2008 & 964104.1 & 323259.2 \\
2009 & 1192248.8 & 423918.4 \\
2010 & 1474981.9 & 544797.8 \\
\hline
\end{tabular}




\begin{tabular}{lll}
\hline Year & PCCBs & IBs \\
\hline 2011 & 1803674.8 & 699696.7 \\
2012 & 2199373.2 & 897632.7 \\
2013 & 2518413.8 & 1013323.1 \\
2014 & 2839550.1 & 1220371.3 \\
2015 & 3207521.3 & 1435806.1 \\
2016 & 3622284.5 & 1639846.6 \\
\hline
\end{tabular}

Source: Scheduled Bank Statistics by Bangladesh Bank.

Though both types of banks have increasing trend in private sector deposit, PCCBs were ahead of IBs in this concern. For both IBs and PCCBs, proportion of private sector deposit is larger than that of public sector.

\subsection{Market Share of Public Sector and Private Sector Deposit by Types of Banks}
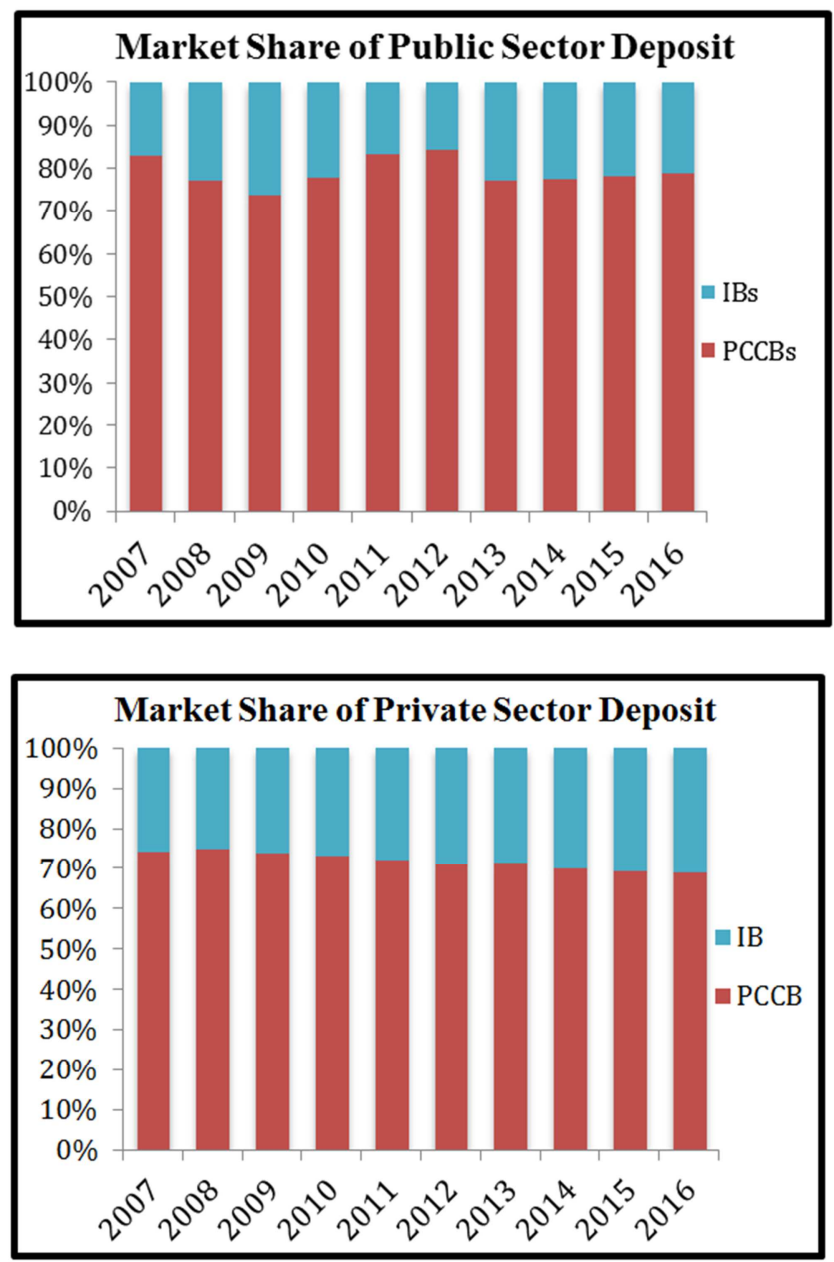

Source: Scheduled Bank Statistics by Bangladesh Bank.

Figure 6. Market Share of Public and Private Sector Deposit.

The above figures show that market share of public sector deposit of IBs fluctuated significantly over last ten years. It captured the maximum in the year 2009 but later on followed a diminishing trend, regained in 2013 and held a stable position over the following years. Where as for private sector deposit, IBs held a consistent position over ten years but the proportion increased slightly during the very recent years.

\subsection{Total Demand Deposit by Types of Banks}

The traders and businessman who have to make a number of payments frequently and regularly generally maintain demand deposits. The depositors can withdraw these deposits at any time by means of cheque. Usually no interest is paid on them hence called non-interest bearing [3]. The following table and figure show the total demand deposit by both types of banks.

Table 7. Total Demand Deposit.

\begin{tabular}{lll}
\hline Year & PCCBs & IBs \\
\hline 2007 & 176506 & 39977 \\
2008 & 203891 & 50763 \\
2009 & 262882 & 63213 \\
2010 & 324203 & 74930 \\
2011 & 354112.98 & 89004 \\
2012 & 419297.33 & 119311.94 \\
2013 & 441006.83 & 123857.4 \\
2014 & 579725.76 & 146615.43 \\
2015 & 665125 & 167098.7 \\
2016 & 800911.4 & 198408.9 \\
\hline
\end{tabular}

Source: Activities of Bank, Insurance and Financial Institutions by Ministry of Finance.

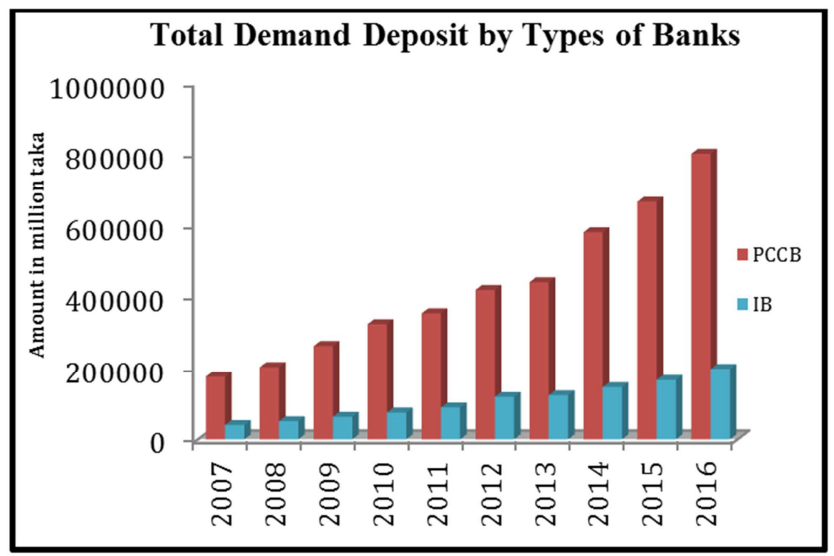

Figure 7. Total Demand Deposit.

Source: Activities of Bank, Insurance and Financial Institutions by Ministry of Finance.

Figure 7 shows that both demand deposit for Islamic banks and private conventional banks increased over the ten years. As evident from previous discussion, PCCBs total demand deposits were much larger than that of IBs.

\subsection{Growth of Total Demand Deposit by Types of Banks}

There remained a fluctuating growth rate of demand deposits by both types of banks. But the average growth rate suggests that IBs were performing better. The demand deposit growth of IBs was higher during 2007 to 2008 though it fell below that of PCCBs soon after that. But recovered well during 2011-2012. The growth rates of demand deposits of both types of bank were lowest in 2013 over these ten years. Very interestingly the demand deposit growth rate had very sharp ups and downs movement. 
Table 8. Growth of Total Demand Deposit.

\begin{tabular}{lll}
\hline Year & PCCBs & IBs \\
\hline 2007 & $26.50 \%$ & $36.06 \%$ \\
2008 & $15.52 \%$ & $26.98 \%$ \\
2009 & $28.93 \%$ & $24.53 \%$ \\
2010 & $23.33 \%$ & $18.54 \%$ \\
2011 & $9.23 \%$ & $18.78 \%$ \\
2012 & $18.41 \%$ & $34.05 \%$ \\
2013 & $5.18 \%$ & $3.81 \%$ \\
2014 & $31.46 \%$ & $18.37 \%$ \\
2015 & $14.73 \%$ & $13.97 \%$ \\
2016 & $20.42 \%$ & $18.74 \%$ \\
Average Growth Rate & $19.37 \%$ & $21.38 \%$ \\
\hline
\end{tabular}

Source: Activities of Bank, Insurance and Financial Institutions by Ministry of Finance.

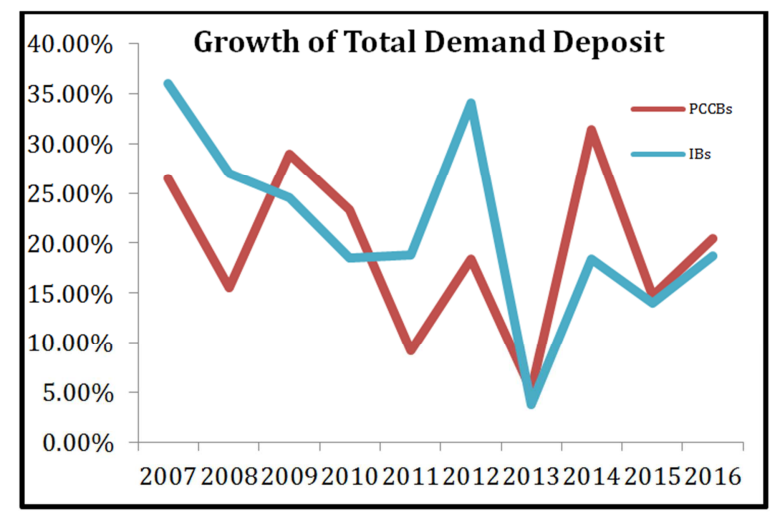

Figure 8. Growth of Total Demand Deposit.

Source: Activities of Bank, Insurance and Financial Institutions by Ministry of Finance.

\subsection{Total Time Deposit by Types of Banks}

A time deposit is an interest-bearing bank deposit that has a specified date of maturity. The following table shows the total amount of time deposit for both types of banks.

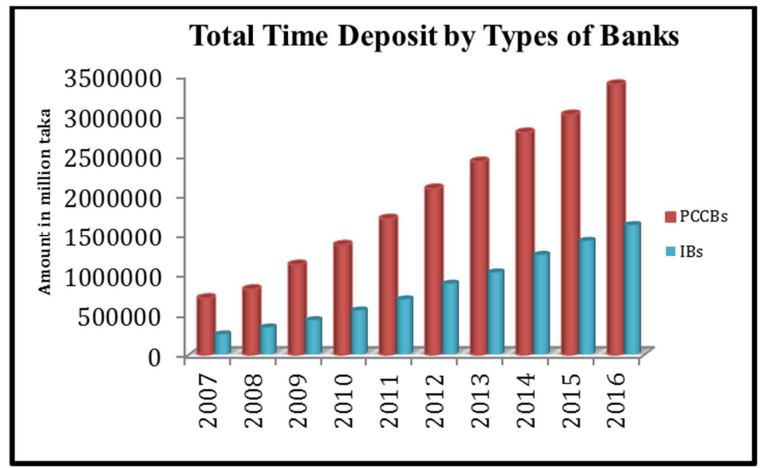

Figure 9. Total Time Deposit.

Source: Activities of Bank, Insurance and Financial Institutions by Ministry of Finance.

Table 9. Total Time Deposit.

\begin{tabular}{lll}
\hline Year & PCCBs & IBs \\
\hline 2007 & 700271 & 250535 \\
2008 & 812032 & 336679 \\
\hline
\end{tabular}

\begin{tabular}{lll}
\hline Year & PCCBs & IBs \\
\hline 2009 & 1118617 & 427786 \\
2010 & 1364629 & 548364 \\
2011 & 1703879 & 686792 \\
2012 & 2082161 & 881438.3 \\
2013 & 2419121 & 1022273.56 \\
2014 & 2781777.1 & 1240814.01 \\
2015 & 3006917.3 & 1414896.4 \\
2016 & 3385268.7 & 1625310.2 \\
\hline
\end{tabular}

Source: Activities of Bank, Insurance and Financial Institutions by Ministry of Finance.

A steady increase of total time deposit for both types of banks has been observed from Figure 9. The time deposits of PCCBs were greater than that of IBs.

\subsection{Growth of Time Deposit by Types of Banks}

As shown in Figure 10, the growth rate of time deposits of both IBs and PCCBs were changing over the ten years. In 2009 PCCBs time deposit growth was the highest and after that it dropped sharply in 2010. The growth rate of time deposit of IBs increased in 2008 but over the subsequent years it fell gradually showing occasional rise in growth. Except for 2009 and 2013 IBs time deposit growth rates were higher than that of PCCBs. Average growth rate for 10 years from Table 10 also focuses IBs enhanced performance.

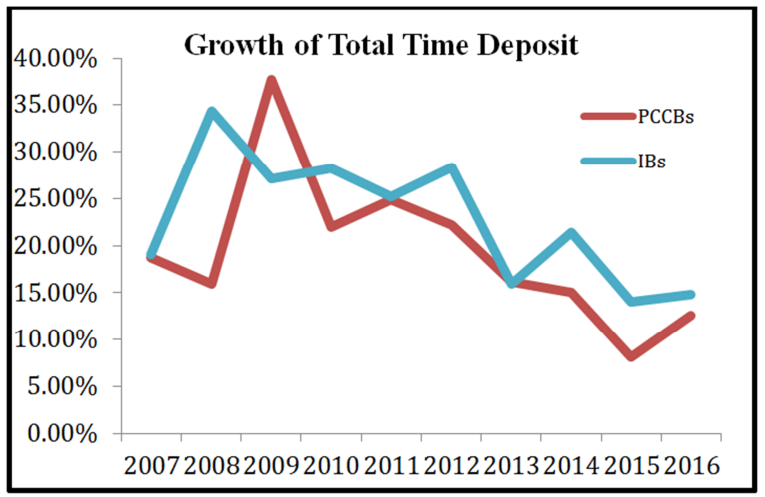

Figure 10. Growth of Total Time Deposit.

Source: Activities of Bank, Insurance and Financial Institutions by Ministry of Finance.

Table 10. Growth of Total Time Deposit.

\begin{tabular}{lll}
\hline Year & PCCBs & IBs \\
\hline 2007 & $18.78 \%$ & $19.12 \%$ \\
2008 & $15.96 \%$ & $34.38 \%$ \\
2009 & $37.76 \%$ & $27.06 \%$ \\
2010 & $21.99 \%$ & $28.19 \%$ \\
2011 & $24.86 \%$ & $25.24 \%$ \\
2012 & $22.20 \%$ & $28.34 \%$ \\
2013 & $16.18 \%$ & $15.98 \%$ \\
2014 & $14.99 \%$ & $21.38 \%$ \\
2015 & $8.09 \%$ & $14.03 \%$ \\
2016 & $12.58 \%$ & $14.87 \%$ \\
Average Growth Rate & $19.34 \%$ & $22.86 \%$ \\
\hline
\end{tabular}

Source: Activities of Bank, Insurance and Financial Institutions by Ministry of Finance. 


\subsection{Employee Productivity and Branch Productivity of Deposit by Types of Banks}

Table 11 and Figure 11 depict the employee productivity by both types of banks. In this case, total deposit for each type of bank is divided by corresponding total number of employees for each year to determine the employee productivity.

Table 11. Deposit per Employee.

\begin{tabular}{lll}
\hline Year & PCCBs & IBs \\
\hline 2007 & 22.89 & 23.35 \\
2008 & 26.42 & 24.00 \\
2009 & 30.70 & 29.06 \\
2010 & 32.97 & 32.35 \\
2011 & 37.02 & 36.59 \\
2012 & 41.26 & 43.02 \\
2013 & 43.59 & 43.39 \\
2014 & 47.37 & 50.74 \\
2015 & 50.49 & 55.74 \\
2016 & 55.21 & 61.27 \\
Average Productivity & 38.79 & 39.95 \\
\hline
\end{tabular}

Source: Activities of Bank, Insurance and Financial Institutions by Ministry of Finance.

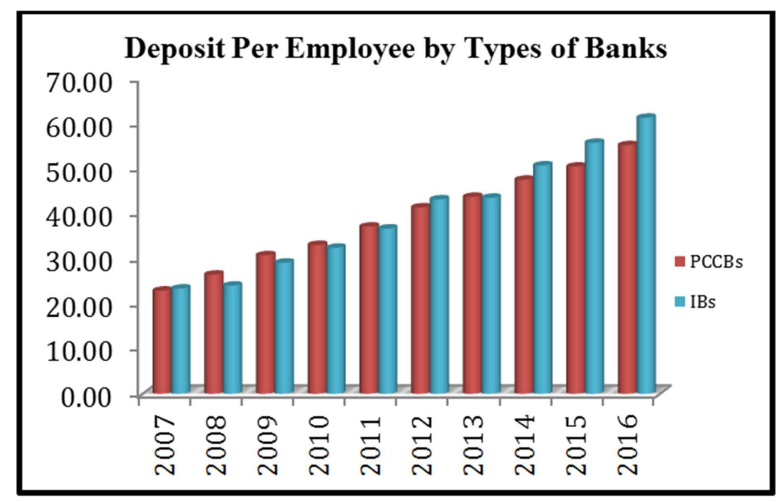

Figure 11. Deposit per Employee.

Source: Activities of Bank, Insurance and Financial Institutions by Ministry of Finance.

In terms of employee productivity PCCBs were ahead of IBs in the earlier years except for 2007 but later from 2014 IBs employee productivity crossed that of PCCBs. Both shows increasing trend and the differences of employee productivity between the two for each year were insignificant over 10 years. On an average, IBs performance is better compared to that of PCCBs as suggested from the average productivity result.

Table 12 below is about the branch productivity for both types of banks. In this case, total deposit for each type of bank is divided by corresponding total number of branches for each year to determine the branch productivity.

Table 12. Deposit per Branch.

\begin{tabular}{lll}
\hline Year & PCCBs & IBs \\
\hline 2007 & 529.57 & 815.31 \\
2008 & 634.43 & 861.89 \\
2009 & 699.77 & 910.79 \\
\hline
\end{tabular}

\begin{tabular}{lll}
\hline Year & PCCBs & IBs \\
\hline 2010 & 762.01 & 968.13 \\
2011 & 837.14 & 1085.47 \\
2012 & 951.41 & 1135.62 \\
2013 & 967.52 & 1066.49 \\
2014 & 1024.27 & 1218.25 \\
2015 & 1088.55 & 1572.61 \\
2016 & 1162.62 & 1680.22 \\
Average Productivity & 865.73 & 1131.48 \\
\hline
\end{tabular}

Source: Activities of Bank, Insurance and Financial Institutions by Ministry of Finance.

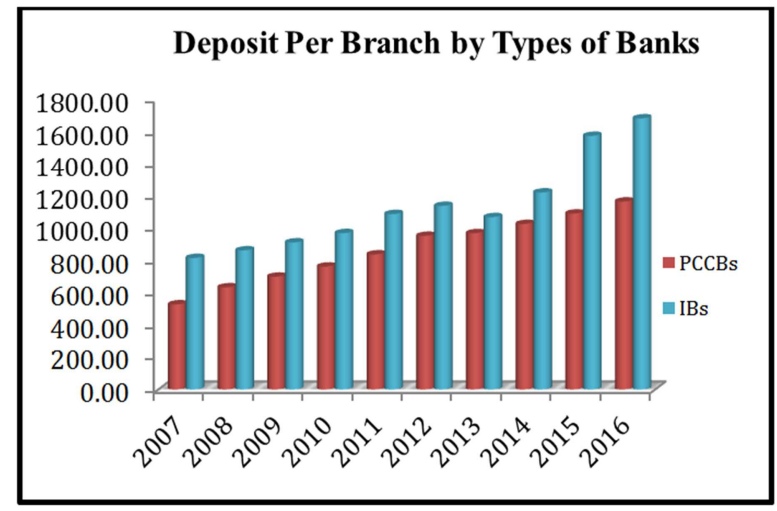

Figure 12. Deposit per Branch.

Source: Activities of Bank, Insurance and Financial Institutions by Ministry of Finance.

Figure 12 shows that branch productivity for both the banks were in increasing trend. Though IBs experienced a drop in 2013. But IBs remained ahead of PCCBs over the ten years in terms of branch productivity. And the amount was quite higher than that of PCCBs. In the year 2015 and 2016, IBs branch productivity shows a large amount and they were the highest over ten years. If we look at the average productivity it shows that IBs are performing better than PCCBs in this regard.

\section{Findings and Conclusions}

Findings for this analysis are quite straightforward and insightful. For most of the variables like total deposit, time deposit, demand deposit, private and public sector deposit, PCCBs are ahead of IBs in terms of total amount since total number of banks is higher for PCCBs. For these variables both types of banks also have rising trends over last ten years. Well, it implies positive performance of overall banking sector since these two types of banks constitute major portion of the banking industry of Bangladesh [4]. Considering the growth aspect it is perceived that on an average IBs performance is better. It shows that IBs have slightly higher average growth rates for total deposit, time deposit and demand deposit compared to that of PCCBs. Although the growth rates for demand and time deposit for both types of banks individually have very inconsistent trend, the total deposit growth seems quite steady. Again for deposit per employee and deposit per branch, IBs average 
productivity is superior compared to that of PCCBs. Not only that, branch productivity of Islamic banks for each year shows higher result compared to that of conventional banks signifying Islamic bank's branches are more efficient in mobilizing deposit. Moreover, a positive perception towards Islamic banks in Bangladesh has been apparent since market share of deposit of IBs are in consistent rise in recent times compared to that of PCCBs. Therefore, it can be concluded that Islamic banks are in stable position regarding deposit performance and thus proper management can help them keep the same pace and enhance the performance more in future. Alongside, PCCBs need to look into the deposit aspects carefully to identify their lags and recover as much as possible.

\section{References}

[1] Ashrafuzzaman, M. and Tanim-Ul-Islam, M. (2015). A Comparative Study of Islamic and Conventional Banking in Bangladesh: Camel Analysis. Journal of Business and Technology, 10 (1).

[2] Al Mahmud, A. and Islam, M. M. (2011). A Comparative Study on Performance Evaluation of Conventional Banks and Islamic Banks in Bangladesh with Special Reference to Islami Bank Bangladesh Limited. Thoughts on Economics, 18(5).

[3] Bangladesh Bank. (2006-2016). Scheduled Bank Statistics. Dhaka.

[4] Bangladesh Bank. (2006-2016). Financial Stability Report. Dhaka.

[5] Chakraborty, J. Salam, F. and Rabbany, Md. G. (2015). Financial Performance Analysis of Islamic Banks in Bangladesh: A Case Study on Islami Bank Bangladesh Limited (IBBL). International Journal of Economics, Finance and Management Sciences, 3(2), pp. 99-106.

[6] Hossain, Md. S. (2015). Comparative Analysis of Financial Performance of Islamic vs. Conventional Banks in Bangladesh. Available at SSRN: https://ssrn.com/abstract=2692975or http://dx.doi.org/10.2139/ssrn.2692975
[7] Hanif, M. (2011). Differences and Similarities in Islamic and Conventional Banking. International Journal of Business and Social Science, 2(2).

[8] Hassan, M. and Lewis, M. (2007). Islamic Banking: An Introduction and Overview. Edward Elgar Publishing.

[9] Hassan, M. (1999). Islamic banking in theory and practice: the experience of Bangladesh. Managerial Finance, 25(5).

[10] Kabir, Md., Qayum, Md. and Islam, M. (2013). Efficiency in Deposit Management of Islami Bank Bangladesh Ltd and Pubali Bank Ltd: A Comparative Study. ASA University Review, 7(1).

[11] Mahbub, M. and Dilshed, H. (2016). Analysis of Financial Performance: A Comparative Study between Private Commercial Conventional \& Islamic Banks in Bangladesh. IOSR Journal of Business and Management, 18(12), pp. 5866.

[12] Ministry of Finance, Government of Bangladesh, (20062016). Activities of Banks, Insurance and Financial Institutions. Dhaka.

[13] Mahal, I. and Rahman, B. (2013). Profitability trend in the banking sector of Bangladesh A comparative study of Islamic and conventional banks. The Bangladesh Accountant.

[14] Noman, A. H. M., Pervin, S., Chowdhury, N. J., Hossain, Md. A., \& Banna, H. (2015). Comparative Performance Analysis between Conventional and Islamic Banks in Bangladesh- An Application of Binary Logistic Regression. Asian Social Science, 11(21).

[15] Sarker, Md. N. I., Sultana, A. and Prodhan, A. Z. M. (2017). Financial Performance Analysis of Islamic Bank in Bangladesh: A Case Study on Al-Arafah Islami Bank Limited. World Journal of Economic and Finance, 3(1), pp. 052-060.

[16] Sarker, Md. (2013). Islamic Banking in Bangladesh: Growth, Structure, and Performance. International Journal of Islamic Financial Services, 1(3).

[17] Yousuf, S., Islam, Md. A., Islam, Md. R. (2014). Islamic Banking Scenario of Bangladesh. Journal of Islamic Banking and Finance, 2(1). 